\title{
Inhibitory effect of Lonchocarpus araripensis lectin in rat acute models of inflammation
}

\author{
ALANA F. PIRES ${ }^{1}$, GABRIELA F.O. MARQUES ${ }^{1}$, NYLANE M.N. DE ALENCAR ${ }^{2}$, MARIA G.Q. MARTINS ${ }^{3}$, \\ MAYARA T.L. DA SILVA ${ }^{3}$, KYRIA S. DO NASCIMENTO ${ }^{3}$, BENILDO S. CAVADA ${ }^{3}$ and ANA MARIA S. ASSREUY ${ }^{1}$
}

\author{
${ }^{1}$ Instituto Superior de Ciências Biomédicas, Universidade Estadual do Ceará, \\ Av. Dr. Silas Munguba, 1700, 60714-903 Fortaleza, CE, Brazil \\ ${ }^{2}$ Núcleo de Pesquisa e Desenvolvimento de Medicamentos/NPDM, Universidade Federal do \\ Ceará, Rua Coronel Nunes de Melo, 1000, 60430-275 Fortaleza, CE, Brazil \\ ${ }^{3}$ Laboratório de Moléculas Biologicamente Ativas/BioMol-Lab, Departamento de Bioquímica e Biologia Molecular, \\ Universidade Federal do Ceará, Campus do Pici, s/n, Bloco 907, 60455-970 Fortaleza, CE, Brazil
}

Manuscript received on September 20, 2018; accepted for publication on January 7, 2019

\begin{abstract}
How to cite: PIRES AF, MARQUES GFO, ALENCAR NMN, MARTINS MGQ, SILVA MTL, NASCIMENTO KS, CAVADA BS AND ASSREUY AMS. 2019. Inhibitory effect of Lonchocarpus araripensis lectin in rat acute models of inflammation. An Acad Bras Cienc 91: e20180991. DOI 10.1590/0001-3765201920180991.
\end{abstract}

\begin{abstract}
Dalbergieae tribe lectins, possessing binding affinity for galactose and mannose, present inflammatory and nociceptive effects, while those for $\mathrm{N}$-acetylglucosamine are anti-inflammatory. Since the anti-inflammatory effect of the seed lectin of L. araripensis (LAL) had been already demonstrated in mice, this effect was presently evaluated in rat models of acute inflammation. LAL $(0.01-1 \mathrm{mg} / \mathrm{kg})$ was administered by intravenous (i.v.) route in male Wistar rats $30 \mathrm{~min}$ before paw edema induction by dextran or carrageenan, and peritonitis by carrageenan. LAL $(1 \mathrm{mg} / \mathrm{kg})$ was incubated with $N$-acetylglucosamine for allowing lectin-sugar interactions before injection into animals. LAL toxicity was evaluated by the parameters: body mass, organs weight, stomach macroscopy, hematological and biochemical dosage. Statistical analysis was performed by ANOVA and Bonferroni's test $(\mathrm{p}<0.05)$. The paw edema induced by carrageenan (AUC: $0.96 \pm 0.09)$ was inhibited by LAL about $39 \%(0-2 \mathrm{~h})$ at all doses, and about $72 \%$ $(3-5 \mathrm{~h})$ at $0.1 \mathrm{and} 1 \mathrm{mg} / \mathrm{kg}$. The increase in the neutrophil migration stimulated by carrageenan was also inhibited by LAL (83\%). In both models, LAL inhibitory effect was prevented by GlcNAc. The subchronic treatment with LAL was well tolerated by animals. LAL possesses anti-inflammatory effect via lectin domain, indicating potential modulator role in cellular inflammatory events.
\end{abstract}

Key words: anti-inflammatory effect, Dalbergieae, lectin domain, leguminous lectin, Loncocharpus araripensis.

\section{INTRODUCTION}

Lectins are glycoproteins, ubiquitously distributed in animal and plant kingdoms, that exhibit specific and reversible carbohydrate-binding properties (Sharon and Lis 1995). In general, the

Correspondence to: Ana Maria Sampaio Assreuy

E-mail: anassreuy@gmail.com

ORCid: https://orcid.org/0000-0002-2323-5385 anti-inflammatory effect of seed lectins isolated from plants belonging to the subtribe Diocleinae (glucose-manose affinity) have been described in several murine animal models by intravenous administration (Assreuy et al. 1997, 1999, Rocha et al. 2011, Pinto et al. 2013).

In respect to plant lectins isolated from the Dalbergieae tribe, those possessing binding affinity for galactose present local inflammatory 
effect, such as the lectins of Vatairea macrocarpa (Alencar et al. 2003, 2004, 2007) and Vatairea guianensis (Marques et al. 2017). On the other hand, those possessing binding affinity for $\mathrm{N}$-acetylglucosamine present systemic anti-inflammatory effect, such as the lectins of Lonchocarpus sericeus (Alencar et al. 2005, Napimoga et al. 2007) and Lonchocarpus araripensis (Pires et al. 2016). In addition, Dalbergiae lectins possessing binding affinity for mannose present pro-inflammatory and nociceptive effects, such as the lectins of Centrolobium tomentosum (Almeida et al. 2016) and Platypodium elegans (Araripe et al. 2017, Cavada et al. 2018), except for the lectin of Andira anthelmia, which presents antinociceptive effect (Nascimento et al. 2016).

As leguminous lectins can reversibly bind to carbohydrates, all the above mentioned effects in animal models of inflammation are closely associated to the lectin carbohydrate binding site, since such effects can be inhibited when the lectins are administered in association with their binding sugars.

Carrageenan is a flogistic agent widely employed to induce experimental acute paw edema in laboratory animals. In mice, carrageenan subplantar injection induces biphasic edema, showing maximal effect in the first phase at $4 \mathrm{~h}$ and in the second phase at $48 \mathrm{~h}$ after injection (Fernandes et al. 2004). However, in rats carrageenan induces uniphasic edema that reaches maximal effect between $3 \mathrm{~h}$ and $4 \mathrm{~h}$ (DiRosa et al. 1971). Since the anti-inflammatory effect of the seed lectin isolated from $L$. araripensis had been already demonstrated in mice, this study aimed to evaluate this effect in two rat models of acute inflammation.

\section{MATERIALS AND METHODS}

DRUGS

Dextran sulfate, carrageenan (lambda type IV) and $\mathrm{N}$-acetylglucosamine (GlcNAc) were purchased from Sigma Chemical (St. Louis, MO, USA). All drugs were solubilized in $0.15 \mathrm{M}$ sterile $\mathrm{NaCl}$ (saline).

\section{LECTIN}

The lectin was isolated from seeds of Lonchocarpus araripensis BENTH (family Leguminosae, tribe Dalbergieae) by affinity chromatography (chitin) followed by ion exchange chromatography (DEAE Sephacel) (Pires et al. 2016). The lectin was solubilized in $0.15 \mathrm{M}$ sterile saline.

\section{ANIMALS}

Male Wistar rats (150-250 g) were maintained in controlled $12 / 12 \mathrm{~h}$ light/ dark cycle at $25^{\circ} \mathrm{C}$ with free access to food and water. The experimental protocols were approved by the Institutional Animal Care and Use Committee of the Universidade Estadual do Ceará (UECE- No 0559924-4).

\section{ANIMALS TREATMENT}

LAL $(0.01,0.1,1 \mathrm{mg} / \mathrm{kg})$ was administered by intravenous (i.v.) route in a final volume of 0.1 $\mathrm{mL} / 100 \mathrm{~g}$ body mass $30 \mathrm{~min}$ before injection of the inflammatory stimuli (carrageenan, dextran). Control animals received the same volume of sterile saline s.c. or i.p.

\section{LECTIN AND BINDING SUGAR}

Lectin, at the most active dose, was incubated with its binding sugar $(0.1 \mathrm{M} \mathrm{GlcNAc})$ for $60 \mathrm{~min}$ at $37^{\circ} \mathrm{C}$ for allowing lectin-sugar interactions before animals i.v. injection. Lectin and sugar were also incubated in separated solutions at the same conditions as controls.

PAW EDEMA MODEL

Paw edema was induced by subcutaneous (s.c.) injection of $300 \mu \mathrm{g}$ carrageenan or dextran into the animals hind paws. Edema was measured by hydroplethysmometry immediately before (zero 
time) s.c. injection of the inflammatory stimuli and at time intervals $(0.5,1-5 \mathrm{~h})$ thereafter, calculated by the subtraction of the basal volume (zero time) and expressed as the variation in paw volume $(\mathrm{ml})$ or area under the time-course curve (AUC; arbitrary units) (Landucci et al. 1995).

\section{PERITONITIS MODEL}

Peritonitis was induced by intraperitoneal (i.p.) injection of carrageenan $(500 \mu \mathrm{g} /$ cavity) and evaluated $4 \mathrm{~h}$ later. Animals were sacrificed and peritoneal fluid harvested with $10 \mathrm{~mL}$ saline (5 IU heparin) for total and differential leukocyte (neutrophils, eosinophils and mononuclear) counts (Souza and Ferreira 1985). Results were expressed as cells per $\mathrm{mL}$ of peritoneal wash.

\section{LAL SYSTEMIC EFFECTS}

- Body mass and organs wet weight: Rats were weighed before and after daily single dose treatment with LAL ( $1 \mathrm{mg} / \mathrm{kg}$; i.v.) or saline (i.v.) for 7 consecutive days. After sacrifice, the liver, kidney, heart and spleen were removed, weighed and expressed as relative to $100 \mathrm{~g}$ body mass.

- Stomach macroscopy: Stomach was opened and exposed for evaluation of the number and grade of gastric mucosal lesions (Santucci et al. 1994).

- Leukogram and blood biochemical parameters: After animals treatment peripheral blood was collected for leukocyte counts (Souza and Ferreira 1985) and biochemical quantification of urea, creatinine, alanine amino transferase (ALT), and aspartate amino transferase (AST) by enzymatic and colorimetric tests.

\section{STATISTICAL ANALYSIS}

Comparisons were determined by ANOVA and Bonferroni's test. Values of $\mathrm{p}<0.05$ were considered significant.

\section{RESULTS}

LAL INHIBITS PAW EDEMA AND PERITONITIS INDUCED BY CARRAGEENAN, BUT NOT THE EDEMA INDUCED BY DEXTRAN

The subcutaneous injection of dextran induced intense paw edema that reached maximal value at $30 \mathrm{~min}(0.70 \pm 0.06 \mathrm{ml} v \mathrm{~s}$. Saline: $0.11 \pm 0.04$ $\mathrm{ml}$ ) and decreased over the following hours after administration. LAL did not alter dextran-induced edema at any doses tested (Figure 1a). Carrageenan also induced intense paw edema that reached maximal value at $4 \mathrm{~h}(0.96 \pm 0.04 \mathrm{ml}$ vs. saline: $0.12 \pm 0.02 \mathrm{ml}$ ) and was maintained until $5 \mathrm{~h}$ after induction (Figure 1b). The i.v. treatment of animals with LAL reduced the edema-time course $(0-2 \mathrm{~h})$ by $33 \%$ (AUC: $0.64 \pm 0.04$ ), $40 \%$ (AUC: $0.56 \pm$ 0.04 ) and $43 \%$ (AUC: $0.55 \pm 0.08$ ) at $0.01,0.1$ and $1 \mathrm{mg} / \mathrm{kg}$, respectively, compared to carrageenan (AUC: $0.96 \pm 0.09$ ). However, in the interval from $3-5 \mathrm{~h}$, the inhibitory effect of LAL was significant only at $0.1(70 \%-$ AUC: $0.56 \pm 0.11)$ and $1(73 \%$ AUC: $0.49 \pm 0.10) \mathrm{mg} / \mathrm{kg}$, compared to carrageenan (AUC: $1.84 \pm 0.09$ ) (Figure 1c, d).

The increase in the number of total leukocytes stimulated by carrageenan $(3366.67 \pm 204$ cells/ $\mathrm{ml}$ ) was inhibited (43\%) by LAL (1903 \pm 234 cells/ $\mathrm{ml}$ ) (Figure 1e). The decrease in the leukocyte migration was mainly due to the LAL inhibitory action by $83 \%$ upon neutrophils (466 \pm 166 cells/ $\mathrm{ml}$ vs. carrageenan: $2704 \pm 274$ cells/ml) (Figure 1f).

THE INHIBITORY EFFECT OF LAL IS REVERSED BY THE LECTIN BINDING SUGAR

The antiedematogenic effect of LAL at $1 \mathrm{mg} /$ kg (AUC: $59 \pm 7 v s$. carrageenan: $158 \pm 10$ ) was partially prevented by the administration of a solution containing LAL associated with GlcNAc (AUC: $80 \pm 9$ ) (Figure 2a), while the LAL inhibitory effect on leukocyte migration was completely 
a)

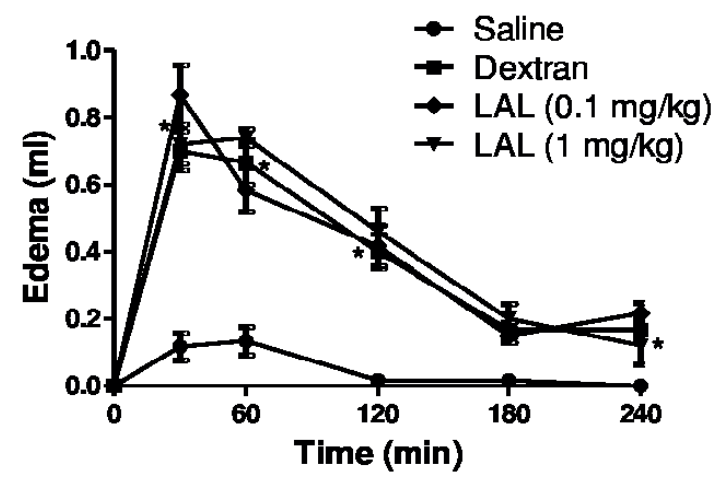

c)

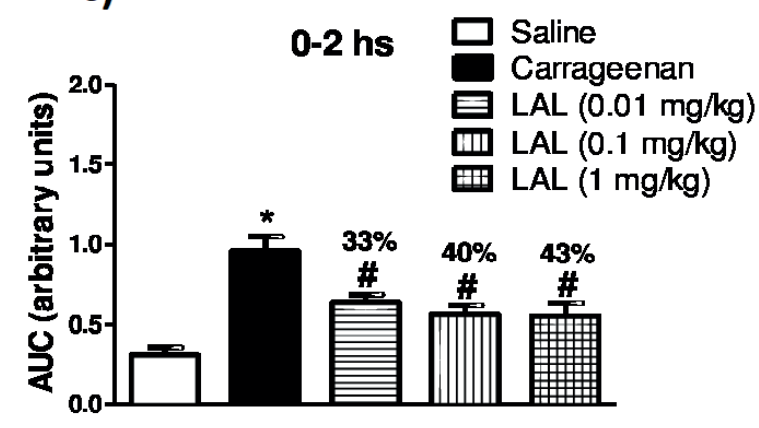

e)

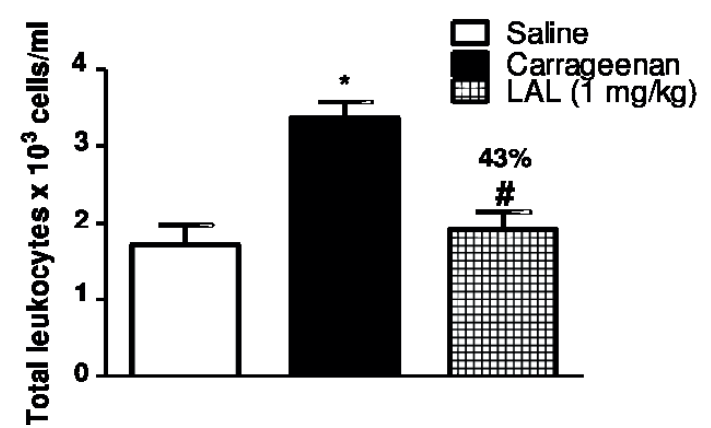

b)

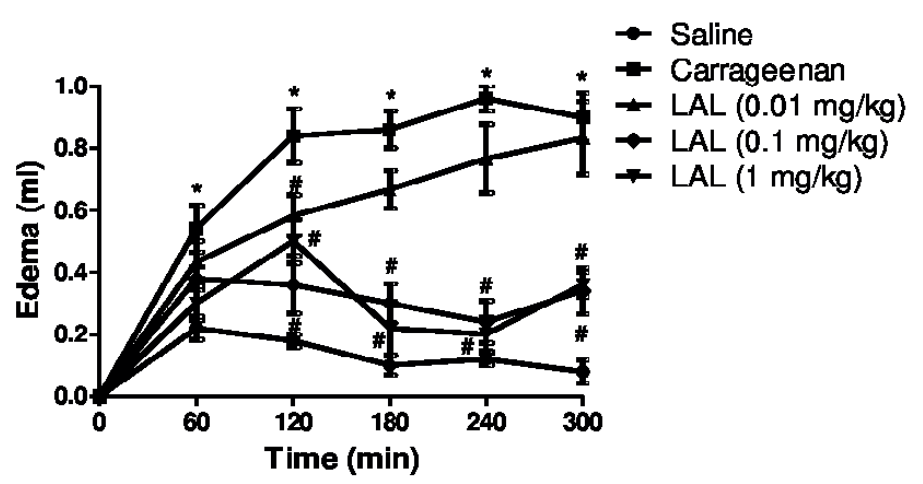

d)

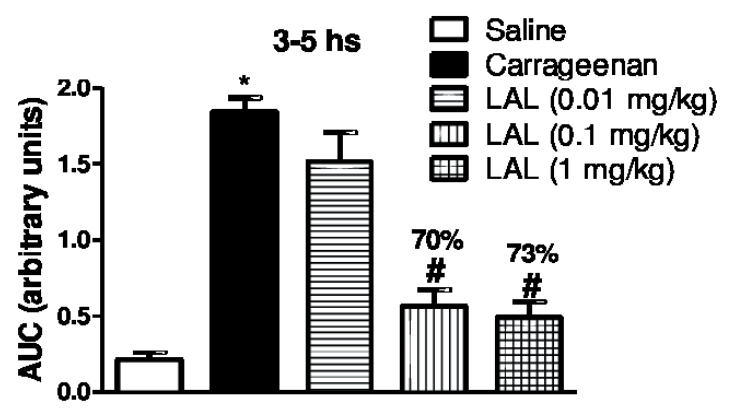

Figure 1 - LAL inhibits paw edema and peritonitis induced by carrageenan. Animals received LAL (0.01 - $1 \mathrm{mg} / \mathrm{kg}$; i.v.) $30 \mathrm{~min}$ before dextran (300 $\mu \mathrm{g} / \mathrm{paw}$; s.c.), carrageenan (300 $\mu \mathrm{g} / \mathrm{paw}$; s.c. or $500 \mu \mathrm{g} /$ cavity; i.p.) or saline $(0.1 \mathrm{ml} / 100 \mathrm{mg}$ body mass; s.c. or i.p.). Edema was evaluated by pletysmometry. (a) Dextran edema time-course; (b) Carrageenan edema time-course; (c, d) Carrageenan edema - Area Under Curve (AUC); (e) Total and (f) differential leukocyte counts evaluated $4 \mathrm{~h}$ after peritonitis induction. Mean \pm S.E.M. $(\mathrm{n}=6)$. ${ }^{*} \mathrm{p}<0.05$ vs. saline; $\# \mathrm{p}<0.05$ vs. carrageenan.

reversed by GlcNAc ( $3183 \pm 391$ cells/ml vs. LAL: $1903 \pm 234$ cells/ml) (Figure 2b).

\section{LAL DOES NOT PRODUCE SYSTEMIC TOXICITY}

The seven-day treatment with LAL $(1 \mathrm{mg} / \mathrm{Kg}$, i.v.) did not affect animals body mass or the wet weight of heart, spleen, kidney or liver compared to controls injected with sterile saline (Table I). All organs appeared normal without edema. The stomach macroscopy showed intact mucosa with no visible lesions. The dosage of urea and creatinine, and the kinetics of the enzymes alanine 
a)

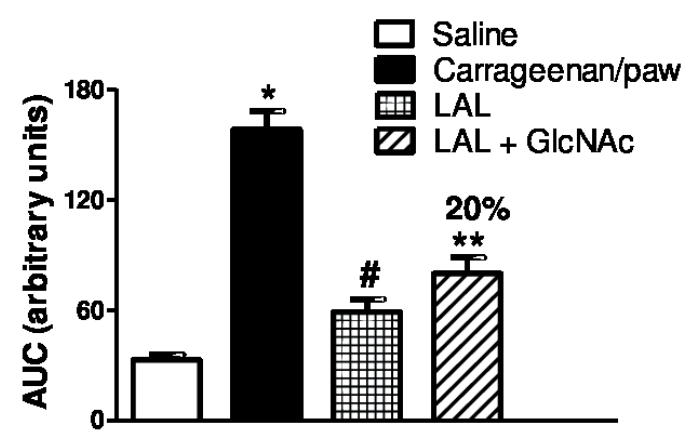

b)

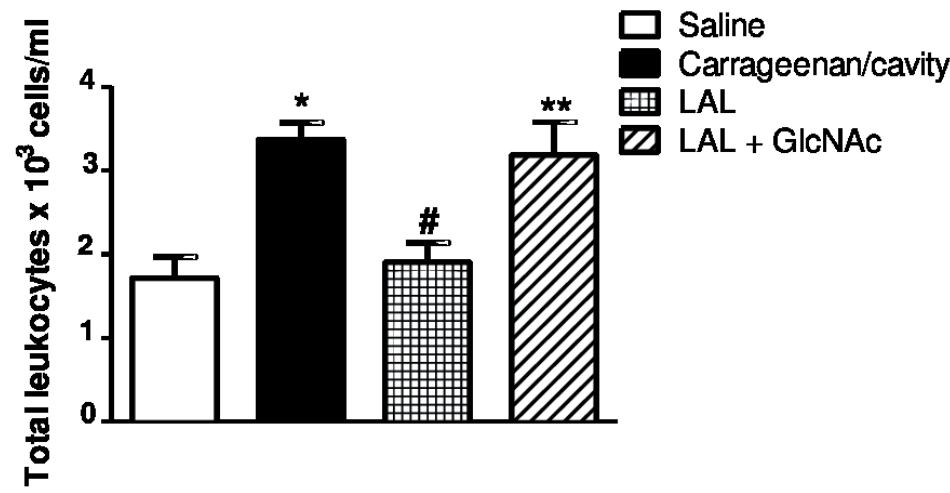

Figure 2 - LAL antiinflamatory effect is reversed by the carbohydrate binding sugar. Animals received LAL (1 mg/kg; i.v.) isolated or associated to $N$-acetylglucosamine (GlcNAc; $0.1 \mathrm{M})$ or saline $(0.1 \mathrm{ml} / 100 \mathrm{mg}$ body mass; s.c.) 30 min before carrageenan (300 $\mu \mathrm{g} / \mathrm{paw}$ or $1 \mu \mathrm{g} /$ cavity). (a) Paw edema (AUC); (b) Total leukocytes (cells x 10³/ml). Mean \pm S.E.M. ( $\mathrm{n}=6$ ). *p $<0.05 v s$. saline; \# $\mathrm{p}<0.05$ vs. carrageenan; $* * \mathrm{p}<0.05$ vs. LAL.

TABLE I

Systemic treatment of rats with LAL does not alter animals body mass, organs wet weight and leukogram

\begin{tabular}{|c|c|c|}
\hline \multirow{2}{*}{ Parameter } & \multicolumn{2}{|c|}{${ }^{\text {a }}$ Treatment $[100 \mu \mathrm{L} / 100 \mathrm{~g}]$} \\
\hline & Saline $[0.9 \%]$ & LAL [1 mg/Kg] \\
\hline${ }^{\mathrm{b}}$ Body mass before treatment & $\mathrm{d} 200.00 \pm 7.7$ & $187.83 \pm 6.08$ \\
\hline${ }^{\mathrm{b}}$ Body mass after treatment & $221 \pm 5.695$ & $210.428 \pm 2.589$ \\
\hline Liver & $6.565 \pm 0.207$ & $6.8238 \pm 0.175$ \\
\hline Kidney & $0.814 \pm 0.048$ & $0.755 \pm 0.029$ \\
\hline Heart & $0.718 \pm 0.063$ & $0.6463 \pm 0.020$ \\
\hline Spleen & $0.668 \pm 0.048$ & $0.6710 \pm 0.043$ \\
\hline${ }^{\mathrm{c}}$ Total leukocytes & $49 \pm 3$ & $54.2 \pm 1.77$ \\
\hline Neutrophils & $43.7 \pm 1.9$ & $46.27 \pm 1.25$ \\
\hline Eosinophils & $14.03 \pm 1.13$ & $14.31 \pm 2.29$ \\
\hline Basophils & $0.12 \pm 0.06$ & $0.014 \pm 1.26$ \\
\hline Monocytes & $2.52 \pm 0.57$ & $4.17 \pm 1.20$ \\
\hline Lymphocytes & $41.67 \pm 2.09$ & $32.23 \pm 4.46$ \\
\hline
\end{tabular}

$\overline{{ }^{\mathbf{a}} \text { Rats were injected daily in single doses with LAL or saline during seven consecutive days; }{ }^{\mathbf{b}} \text { before and after treatment, animals }}$ and organs weighed and ${ }^{\mathbf{c}}$ blood samples collected for leukogram count. ${ }^{\mathbf{d}}$ Mean \pm S.E.M. ( $\mathrm{n}=7$ ). Student $t$ test for unpaired values.

amine transferase (ALT) and aspartate amine transferase (AST), used as markers of renal and hepatic function, respectively, did not differ from controls. The osmotic equilibrium, seen by the dosage of plasma albumin and globulin, was either unchanged, demonstrating that LAL confers excellent tolerance to animals. Also, the number of blood circulating leukocytes was unaltered by the treatment suggesting that LAL does not promote leukocyte agglutination or secondary effects in lymphoid tissues, therefore preserving the number of defense cells (Table II). 


\section{DISCUSSION}

The present study demonstrates in rats the antiinflammatory effect of Lonchocarpus araripensis lectin in acute inflammatory models.

In addition to the documented role of endogenous mammalian lectins, exogenous lectins also exhibit immunomodulatory function (Rabinovich and Croci 2012). It has been shown that plant lectins possess anti- or pro-inflammatory effect in several murine models, being theses effects dependent on the administration route or the lectin binding sugar (Assreuy et al. 1997, 2009, Marques et al. 2017, Napimoga et al. 2007). In general, lectins isolated from the genus Lonchocarpus show anti-inflammatory pattern either in mice or rat models of acute inflammation (Assreuy et al. 1999, Alencar et al. 2005, Napimoga et al. 2007), except for LAL, being previously demonstrated only in mice (Pires et al. 2016).

It is known that edema formation is a synergic response involving various inflammatory mediators which results in increased vascular permeability and/ or blood flow (Williams and Peck 1977). Dextran is an inflammatory substance that elicits osmotic edema involving the participation of histamine, but also serotonin and bradykinin (Lo et al. 1982). However, carrageenan induces a multimediated edema accompanied by protein-rich exudate and intense leukocyte infiltrate (DiRosa et al. 1971). In this study, LAL presented selective anti-dematogenic effect, since inhibited only that induced by carrageenan. However, LAL activity at vascular level could not be excluded, since it inhibited the first hour of the edema time-course elicited by carrageenan. LAL inhibition of vascular inflammation events had being already demonstrated in mice (Pires et al. 2016).

Albeit LAL anti-inflammatory effect had been demonstrated in mice, via reduction of the leukocyte rolling and adhesion induced by carrageenan (Pires et al. 2016), this effect was reproduced here in rat, since LAL inhibited the neutrophil migration
TABLE II

Systemic treatment of rats with LAL does not alter plasma biochemical profile.

\begin{tabular}{ccc}
\hline \multirow{2}{*}{ biochemical dosage } & \multicolumn{2}{c}{${ }^{\mathbf{a}}$ Treatment $[\mathbf{1 0 0} \boldsymbol{\mu L} / \mathbf{1 0 0 g}]$} \\
\cline { 2 - 3 } & Saline $[\mathbf{0 , 9 \%}]$ & LAL $[\mathbf{1 m g} / \mathbf{K g}]$ \\
\hline Urea [mg/dl] & ${ }^{\mathbf{c}} 67.45 \pm 2.02$ & $68.32 \pm 2.00$ \\
Creatinin [mg/dl] & $0.481 \pm 0.06$ & $0.55 \pm 0.08$ \\
AST [U/L] & $96.2 \pm 18.34$ & $114.2 \pm 5.72$ \\
ALT [U/L] & $25.83 \pm 2.78$ & $36.77 \pm 7.13$ \\
Total Protein [g/dl] & $7.283 \pm 0.18$ & $7.29 \pm 0.12$ \\
Albumin [mg/dl] & $4.406 \pm 0.05$ & $3.80 \pm 0.06$ \\
Globulin [mg/dl] & $2.87 \pm 0.16$ & $3.49 \pm 0.15$ \\
\hline
\end{tabular}

${ }^{a}$ Rats were injected daily in single doses with LAL or saline during seven consecutive days; ${ }^{\mathbf{b}}$ After treatment, blood samples were collected for biochemical dosage. ${ }^{\mathbf{c}}$ Mean \pm S.E.M. $(\mathrm{n}=7)$. Student $t$ test for unpaired values. ALT=alanine amine transferase; AST=aspartate amine transferase.

induced by carageenan. It is important to highlight that different degrees in biological activities of leguminous lectins had been previously reported, correlated to species, animals and/or experimental models (Assreuy et al. 2009, Bento et al. 1993, Cavada et al. 2001). In this line, LAL has shown more efficacy in the anti-inflammatory activity (83\%) compared to L. sericeus lectin in rat (51\%) (Alencar et al. 1999) and LAL in mice (70\%) (Pires et al. 2016).

Leukocyte endothelial adhesion requires carbohydrate interaction, which is a pre requisite for the movement of leukocytes from blood into tissues, an inflammation feature (Rabinovich and Croci 2012). Similar to other plant lectins, the antiinflamatory effect of LAL is mediated by interaction with carbohydrate, providing that lectin-glycan binding is a mean of molecular recognition, by which the organisms use to identify and decode biological information (Rabinovich and Croci 2012).

Another important finding of this study was that LAL treatment was well tolerated by rats, since no mortality or alterations in body and organ mass, hematological and biochemical parameters were 
observed, in accordance to previous study in mice (Pires et al. 2016).

In conclusion, the present study demonstrated that the lectin isolated from Lonchocarpus araripensis seeds possess antiinflammatory effect via lectin domain, in the rat models of paw edema and peritonitis induced by carrageenan, by reduction of neutrophil infiltration.

\section{ACKNOWLEDGMENTS}

Financial support of Fundação Cearense de Amparo à Pesquisa (FUNCAP), Coordenação de Aperfeiçoamento de Pessoal de Nível Superior (CAPES) and Conselho Nacional de Desenvolvimento Científico e Tecnológico (CNPq). Drs. A.M.S. Assreuy and B.S. Cavada are senior investigators of CNPq.

\section{AUTHOR CONTRIBUTIONS}

Maria Gleiciane Q. Martins and Mayara T.L. Silva performed the lectin isolation and purification under supervision of Kyria S. Nascimento and Benildo S. Cavada; Alana F. Pires and Gabriela F.O. Marques performed the biological assays and analyzed the results; Nylane Maria N. Alencar performed the toxicity assays; Ana Maria S. Assreuy, as the group leader, analyzed results and performed major manuscript corrections. All authors had read, corrected and approved the final manuscript version.

\section{REFERENCES}

ALENCAR NM, ASSREUY AM, ALENCAR VB, MELO SC, MV RAMOS, CAVADA BS, CUNHA FQ AND RIBEIRO RA. 2003. The galactose-binding lectin from Vatairea macrocarpa seeds induces in vivo neutrophil migration by indirect mechanism. Int J Biochem Cell Biol 12: 16741681.

ALENCAR NM, ASSREUY AM, CRIDDLE DN, SOUZA EP, SOARES PM, HAVT A, ARAGÃO KS, BEZERRA DP, RIBEIRO RA AND CAVADA BS. 2004. Vatairea macrocarpa lectin induces paw edema with leukocyte infiltration. Protein Peptide Lett 2: 195-200.
ALENCAR NM, ASSREUY AM, HAVT A, BENEVIDES RG, DE MOURA TR, DE SOUSA RB, RIBEIRO RA, CUNHA FQ AND CAVADA BS. 2007. Vatairea macrocarpa (Leguminosae) lectin activates cultured macrophages to release chemotactic mediators. N-S Arch Pharmacol 4: 275-282.

ALENCAR NM, CAVALCANTE CF, VASCONCELOS MP, LEITE KB, ARAGÃO KS, ASSREUY AM, NOGUEIRA NA, CAVADA BS AND VALE MR. 2005. Antiinflammatory and antimicrobial effect of lectin from Lonchocarpus sericeus seeds in an experimental model of infectious peritonitis. J Pharm Pharmacol 7: 919-922.

ALENCAR NM, TEIXEIRA EH, ASSREUY AM, CAVADA BS, FLORES CA AND RIBEIRO RA. 1999. Leguminous lectins as tools for studying the role of sugar residues in leukocyte recruitment. Mediators Inflamm 2: 107-113.

ALMEIDA AC ET AL. 2016. Structural analysis of Centrolobium tomentosum seed lectin with inflammatory activity. Arch Biochem Biophys 596: 73-83.

ARARIPE DA ET AL. 2017. Partial characterization and immobilization in CNBr-activated Sepharose of a native lectin from Platypodium elegans seeds (PELa) and comparative study of edematogenic effect with the recombinant form. Int J Biol Macromol 102: 323-330.

ASSREUY AM, FONTENELE SR, PIRES AF, FERNANDES DC, RODRIGUES NV, BEZERRA EH, MOURA TR, DO NASCIMENTO KS AND CAVADA BS. 2009. Vasodilator effects of Diocleinae lectins from the Canavalia genus. N-S Arch Pharmacol 6: 509-521.

ASSREUY AM, MARTINS GJ, MOREIRA ME, BRITO GA, CAVADA BS, RIBEIRO RA AND FLORES CA. 1999. Prevention of cyclophosphamide-induced hemorrhagic cystitis by glucose-mannose binding plant lectins. J Urology 6: 1988-1993.

ASSREUY AM, SHIBUYA MD, MARTINS GJ, DE SOUZA ML, CAVADA BS, MOREIRA RA, OLIVEIRA JT, RIBEIRO RA AND FLORES CA. 1997. Antiinflammatory effect of glucose-mannose binding lectins isolated from Brazilian beans. Mediators Inflamm 3: 201210.

BENTO CA, CAVADA BS, OLIVEIRA JT, MOREIRA RA AND BARJA-FIDALGO C. 1993. Rat paw edema and leukocyte immigration induced by plant lectins. Agents Actions 1-2: 48-54.

CAVADA BS ET AL. 2018. Structural studies and nociceptive activity of a native lectin from Platypodium elegans seeds (nPELa). Int J Biol Macromol 107: 236-246.

CAVADA BS, BARBOSA T, ARRUDA S, GRANGEIRO TB AND BARRAL-NETTO M. 2001. Revisiting proteus: Do minor changes in lectin structure matter in biological activity? Lessons from and potential biotechnological uses of the Diocleinae subtribe lectins. Curr Protein Pept Sc 2: 123-135. 
DI ROSA M, GIROUD JP AND WILLOUGHBY DA. 1971. Studies on the mediators of the acute inflammatory response induced in rats in different sites by carrageenan and turpentine. J Pathol 104: 15-29.

FERNANDES D AND ASSREUY J. 2004. Involvement of guanylate cyclase and potassium channels on the delayed phase of mouse carrageenan-induced paw oedema. Eur J Pharmacol 1-3: 209-214.

LANDUCCI ECT, ANTUNES E, DONATO JL, FARO R, HYSLOP S, MARANGONI S, OLIVEIRA B, CIRINO G AND DE NUCCI G. 1995. Inhibition of carrageenininduced rat paw edema by crotapotin, a polypeptide complexed with phospholipase $\mathrm{A}_{2}$. Br J Pharmacol 114: 578-583.

LO TN, ALMEIDA AP AND BEAVEN MA. 1982. Dextran and carrageenan evoke different inflammatory response in rat with respect to composition of infiltrates in effect of indomethacin. J Pharmacol Exp Ther 221: 261-267.

MARQUES GFO ET AL. 2017. Contribution of the carbohydrate-binding ability of Vatairea guianensis lectin to induce edematogenic activity. Biochimie 140: 58-65.

NAPIMOGA MH ET AL. 2007. Lonchocarpus sericeus lectin decreases leukocyte migration and mechanical hypernociception by inhibiting cytokine and chemokines production. Int Immunopharmacol 6: 824-835.

NASCIMENTO KS, NASCIMENTO FL, SILVA MT, NOBRE CB, MOREIRA CG, BRIZENO LA, DA PONTE EL, ASSREUY AM AND CAVADA BS. 2016. Purification of a thermostable antinociceptive lectin isolated from Andira anthelmia. J Mol Recognit 6: 248-252.

PINTO NV, CAVADA BS, BRITO LF, PEREIRA RI, DA SILVA MT, CASTRO RR, DE FREITAS PIRES A AND
ASSREUY AM. 2013. Effects of Canavalia lectins on acute inflammation in sensitized and non-sensitized rats. Inflammation 3: 713-722.

PIRES AF, RODRIGUES NV, SOARES PM, RIBEIRO RA, ARAGÃO KS, MARINHO MM, DA SILVA MT, CAVADA BS AND ASSREUY AM. 2016. A novel $\mathrm{N}$-acetyl-glucosamine lectin of Lonchocarpus araripensis attenuates acute cellular inflammation in mice. Inflamm Res 1: 43-52.

RABINOVICH GA AND CROCI DO. 2012. Regulatory circuits mediated by lectin-glycan interactions in autoimmunity and cancer. Immunity 36: 322-335.

ROCHA BA ET AL. 2011. Structural basis for both pro- and anti-inflammatory response induced by mannose-specific legume lectin from Cymbosema roseum. Biochimie 5: 806-816.

SANTUCCI L, FIORUCCI S, GIANSANTI M, BRUNORI PM, DI MATTEO FM AND MORELLI A. 1994. Pentoxifylline prevents indomethacin induced acute gastric mucosal damage in rats: role of tumour necrosis factor alpha. Gut 35: 909-915.

SHARON N AND LIS H. 1995. Lectins-proteins with a sweet tooth: functions in cell recognition. Essays Biochem 30: 59-75.

SOUZA GEP AND FERREIRA SH. 1985. Blockade by anti macrophage serum of the migration of PMN neutrophils into the inflammed peritoneal cavity. Agents Actions 17: 97-103.

WILLIAMS TJ AND PECK MJ. 1977. Role of prostaglandinmediated vasodilatation in inflammation. Nature 5637 : 530-532. 